\section{The Use of Plastic Films and Sprayable Reflective Particle Films to Increase Light Penetration in Apple Canopies and Improve Apple Color and Weight}

\author{
D. Michael Glenn ${ }^{1,3}$ and G.J. Puterka ${ }^{2}$ \\ U.S. Department of Agriculture, Agricultural Research Service, Appalachian \\ Fruit Research Station, 2217 Wiltshire Road, Kearneysville, WV 25430
}

Additional index words. Malus domestica, kaolin, 'Empire', hue angle, reflective mulch red/far-red ratio

\begin{abstract}
The objective of the present study was to examine the effect of a reflective, aluminized plastic film (APF), a reflective, particle-based film applied to the tree (PFT), a reflective, particle film applied to the west side of the tree (PFW), or a particle-based reflective film applied to the grass between tree rows (RPF) on 'Empire' apple [Malus domestica (Borkh.)] color and fruit weight in a multiyear study. The APF treatment consistently increased red color and was the only treatment to increase fruit red color from the lower portion of the west side of the tree. The PFT, PFW, and RPF treatments inconsistently improved apple red color. The APF treatment reflected $\approx 6$ times the amount of photosynthetically active radiation $(P A R)$ as the RPF and reflected different red/far-red light ratios (R/FR). In all years, average fruit weight was increased by the RPF, PFT, and PFW treatments compared with the untreated control and APF treatment. The mechanism responsible for the increased fruit weight may be the altered light quality, not quantity, reflected from the RPF treatments. The reflected light has enhanced far-red radiation, which may have beneficial effects on both fruit color and fruit weight. The effect of enhanced far-red radiation on increased fruit weight may be a phytochrome-mediated process affecting dry matter partitioning.
\end{abstract}

Increasing light penetration into fruit tree canopies is an established means of improving fruit color and fruit size. Training systems (Hampson et al., 2004), growth regulators (Miller, 1988), plant nutrition (Williams and Billingsley, 1974), and reflective films (Layne et al., 2001, 2002; Miller and Greene, 2003) are techniques that improve fruit quality entirely or in part by improving light penetration into the tree canopy. Reflective films have been developed to reflect narrow bands of light (Kasperbauer, 1999) or the entire spectrum using white (Grout et al., 2004) or metallized films (Layne et al., 2001, 2002; Miller and Greene, 2003). Reflective films increase red color development in apple, primarily in the lower half of the canopy (Moreshet et al., 1975) and may alter date of fruit maturation (Miller and Greene, 2003). Layne et al. (2001, 2002) measured increased ultraviolet A radiation (UVa) (330-400 nm), photosynthetically active radiation $(P A R)(400-700 \mathrm{~nm})$, and near-

Received for publication 19 July 2006. Accepted for publication 29 Sept. 2006.

We thank the Engelhard Corporation for their financial support of this research and Bruce Lamp inen, U. of Ca., Dept. of Pomology, for assistance in constructing the PAR sensors.

${ }^{1}$ Soil scientist.

${ }^{2}$ Entomologist.

${ }^{3}$ To whom reprint requests should be addressed e-mail michael.glenn@ars.usda.gov. infrared radiation (NIR) $(700-1100 \mathrm{~nm})$ reflection from a reflective film and a resulting increased air temperature within the canopy and found that the red light/far-red light ratio (R/FR) of the reflective film was similar to incoming radiation. Grout et al. (2004) also found that a white woven film had a similar $\mathrm{R} / \mathrm{FR}$ ratio as sunlight. Reflective films with a narrow band of light reflection increased yield of other horticultural crops by decreasing the R/FR (Kasperbauer, 2000; Kasperbauer and Hunt, 1998; Kaul and Kasperbauer, 1992; Matheny et al., 1992). Decreasing the $\mathrm{R} / \mathrm{FR}$ influences many aspects of plant development, including plant architecture (Kasperbauer and Karlen, 1986; Rajapakse and Kelly, 1992), carbohydrate partitioning (Fortnum and Kasperbauer, 1992; Kasperbauer 1987, 1992; Kasperbauer and Hunt, 1992), photosynthetic efficiency (Kasperbauer, 1988), and concentrations of various metabolites (Antonious and Kasperbauer, 2002; Kasperbauer and Loughrin, 2004) through phytochrome-mediated processes. Colored netting, while reducing light, can also increase yield (Shahak et al., 2004). Despite the increased light levels in the canopy from reflective films, increased fruit size is infrequently documented according to Miller and Greene (2003); only Moreshet et al. (1975) and Grout et al. (2004) document an (1995) state that PAR interception by the canopy can be increased as much as $40 \%$ with reflective films. Therefore, the lack of inincrease in apple yield and size. Green et al. creased productivity suggests that light quality may be a factor in reflected light from these films. Miller and Greene (2003) demonstrated an economic benefit of reflective films for a high-density metallized silver polyethylene film in apple production resulting from improved color development. The use of a kaolin-based particle film material has inconsistently increased apple color (Glenn et al., 2001, 2003, 2005). The objective of the present study was to examine the effect of an aluminized plastic film (APF) and a particle-based reflective film applied to the tree (PFT and PFW) and the grass (RPF) between tree rows, each with different R/FR reflection characteristics, on apple color and fruit weight.

\section{Materials and Methods}

Studies were conducted at the USDAARS Appalachian Fruit Research Station, Kearneysville, W.Va. The apple orchard was a moderate density planting (500 trees/ ha at $6.0 \times 3.3-\mathrm{m}$ spacing) of 'Empire'/M.7A planted in 1992 in a north/south orientation. The trees were not irrigated. A separate group of trees was used in each year. In all years, the trees were hand-thinned at postbloom. All treatments were oversprayed with conventional pesticides to protect from disease or insect damage. Conventional orchard practices were used in tree training to an unsupported central leader system and weed control.

The treatments were: 1) nontreated control, 2) RPF applied to the grass, 3) PFT, 4) PFT + RPF, 5) particle film applied only to the west side (PFW) of the tree, 6) PFW + $\mathrm{RPF}$, and 7) APF applied to the grass. The RPF and APF treatments were applied to the 2-m-wide Kentucky tall fescue (Festuca arudinaceae Schreb.) grass middle between the tree rows. The APF was a 1.5 -m-wide, $0.032-\mathrm{mm}$ metallized polyethylene film (Clarke Ag Plastics, Greenwood, Va.). The RPF was $95 \%$ processed kaolin from Engelhard Corp. Iselin, N.J., with a more rain-fast formulation than Surround WP Crop Protectant (Engelhard Corp. Iselin, N.J.). The RPF was applied as a $6 \%$ suspension of material applied at $374 \mathrm{~L} \cdot \mathrm{ha}^{-1}$ with a herbicide boom sprayer to cover the 2-m grass strip. All treatments were applied 2 weeks after petal fall and maintained until harvest. The RPF was reapplied every 2 weeks as a result of the growth of the grass. The grass was not cut in the RPF treatment but was cut for the untreated, PFT, PFW, and APF treatments. The APF was installed 2 weeks after petal fall and replaced if damaged by tractor traffic. The PFT and PFW treatments were $3 \%\left(28.0 \mathrm{~kg} \cdot \mathrm{ha}^{-1}\right)$ applications of Surround. The PFT and PFW treatments were applied using an orchard blast sprayer delivering 935.4 L $\cdot \mathrm{ha}^{-1}$. PFT and PFW treatments were applied biweekly until harvest (seven applications). Control treatments were not sprayed.

The experiment was a randomized block design with three rows of three trees per plot and four replications in 2002 and six 
replications in 2003 and 2004. The middle tree of the middle row was sampled at harvest. At harvest, all fruit were weighed and counted in each plot. In 2002, fruit were harvested after optimum maturity and only hue angle was measured. In 2003 and 2004, fruit were harvested at optimum maturity for storage based on firmness, starch index, and soluble solids concentration (SSC). Ten randomly selected fruit/subsamples were collected at harvest for quality evaluation from the east and west sides of the tree. In 2002 and 2003, the fruit subsamples were collected from a 1- to 2-m height from the outer 30- to $50-\mathrm{cm}$ canopy depth. In 2004, the fruit sampling was further stratified into: 1) bottom of the tree to $1.5-\mathrm{m}$ height and the exposed $30-\mathrm{cm}$ depth of the canopy (low), 2) 2- to $3-\mathrm{m}$ height and the exposed $30-\mathrm{m}$ depth of the canopy (high), and 3) 1 - to $2.5-\mathrm{m}$ height and the shaded canopy from the tree axis to within $50 \mathrm{~cm}$ of the canopy edge (inside). Firmness was determined using the McCormick fruit pressure tester (EFFEGI Corp., Torino, Italy) equipped with an 11.1$\mathrm{mm}$ probe. External color was determined using the Commission Internationale d'Eclairage (CIE) $L^{*}, a^{*}, b^{*}$ color space coordinates. Hue angle was calculated from these data. Four measurements for color were made at $90^{\circ}$ intervals around the equatorial axis of each fruit. SSC was determined from an aliquot of expressed juice from a longitudinal slice from each of 10 fruit. SSC was measured with an Abbe type refractometer (10,450; American Optical Scientific Instruments Div., Buffalo, N.Y.) with a sucrose scale calibrated at $20{ }^{\circ} \mathrm{C}$. Statistical analysis of hue angle was based on a randomized block design. Fruit weight was analyzed using analysis of covariance (PROC GLM) in a randomized complete block design using SAS (Statistical Analysis System, Cary, N.C.; version 8). Fruit number per tree was the independent covariate because average fruit size is inversely related to the number of fruit on the tree. Adjusted treatment means were compared using PDIFF, which compares least squares means with the analysis of covariance.

A separate study area was used to measure canopy $P A R$ levels. In this study, a repeatedmeasures design was used in which the same three trees received sequential treatment. The three trees were separated by a guard tree. In 2002, canopy $P A R$ levels were measured by inserting a quantum line sensor (model LI191SA; LICOR, Lincoln, Nebr.) $1 \mathrm{~m}$ into the canopy at $0.3-$ and $1.5-\mathrm{m}$ heights at six positions in the canopy: 1-m north of the tree axis, at the tree axis, $1-\mathrm{m}$ south of the tree axis, each on the east and west side of the tree. The sensor was leveled at each position with a separate bubble level. Canopy $P A R$ measurements at the $1.5-\mathrm{m}$ height were oriented: up, down, north, and south. At the 0.3$\mathrm{m}$ height, measurements were oriented up and down only. At the time the canopy PAR level was measured, a simultaneous measurement of incoming $P A R$ was recorded and canopy $P A R$ levels were calculated as the quotient of total incoming light at the six positions divided by the incoming light of an unshaded quantum line sensor above the canopy at $3 \mathrm{~m}$, subtracted from 1 , and expressed as a percentage. At each position, a registration point was identified so the quantum line sensor was placed in the same position for each sampling. Measurements were taken within $10 \mathrm{~min}$ of the same time each sampling day and data were collected at $2 \mathrm{~h}$ before solar noon and $1 \mathrm{~h}$ after solar noon. Data were collected only on full sun days. The control treatment was the untreated tree and untreated grass middle. When 3 days of data were collected from the control treatment, all trees in the study area and the two adjacent rows were sprayed with two applications of 3\% Surround on 2 sequential days. The PFT treatment was applied using an orchard blast sprayer delivering $935.4 \mathrm{~L} \cdot \mathrm{ha}^{-1}$. Canopy PAR levels were measured as described previously for 3 full sun days and then the grass row middles on each side of the sampled tree row were treated with the RPF. Canopy PAR levels were measured as described previously. The repeated-measures design had three treatments, three single tree replicates, and six positions at each treatment level. Data were collected in July. This study measured PAR levels within the same trees receiving sequential treatments: (1), (3), and (4) as described previously.

In 2003, PAR sensor clusters were installed in the interior of each tree to measure diurnal PAR levels within the canopy. The $P A R$ sensors were constructed of visible light sensitive silicon chips (Gasp G2711-01; Hammamatsu Inc., Bridgewater, N.J.). The sensors were attached to a metal pole at 1- and 2-m heights from the soil surface and oriented south to eliminate shade from the pole. The sensor mast was driven into the soil and attached to structural wood of the tree to ensure no movement over time. Four silicon sensors were clustered at each height: one upward, one downward, one east, and one west. All four sensors were wired in parallel so that the sum of their output (millivolts) was measured by the CR-7 datalogger (Campbell Scientific, Logan, Utah). This design integrated $P A R$ from all directions within the canopy. Data were collected as a 10-min average and then an hourly and daily sum calculated for data analysis. Daily $P A R$ interception was calculated as the quotient of mean daily incoming light at 1 and $2 \mathrm{~m}$ divided by the incoming light of the unshaded sensor above the canopy at $3 \mathrm{~m}$ and subtracted from 1. Data were collected from 1000 to $1900 \mathrm{HR}$ and expressed as a percentage. The sensor masts were installed 60 to 80 $\mathrm{cm}$ inside the canopy. Incoming $P A R$ was also measured using a $1-\mathrm{m}$ quantum line sensor located in a nonshaded area adjacent to the study area. The Hammamatsu sensor at $3 \mathrm{~m}$ was highly correlated with the LICOR quantum sensor $(r=0.99)$. A similar arrangement of trees was used as in 2002. The three measured trees were separated by a guard tree and four sensor masts were installed around each tree: $1 \mathrm{~m}$ north of the tree axis, $1 \mathrm{~m}$ south of the tree axis, each on the east and west side of the tree. The initial treatment was the untreated tree and untreated grass middle. When $3 \mathrm{~d}$ of data were collected from the control treatment, the APF material was applied to the grass row middle of the two rows adjacent to the sampled tree row. Canopy PAR levels were measured as described previously for 3 full sun days and then the grass row middles on each side of the sampled tree row were treated with RPF. Canopy $P A R$ levels were measured as described previously. The repeated measures design had three treatments, three single tree replicates, and four positions at each treatment level. Data were collected in August and early September, but further sampling was interrupted by a hurricane that removed all fruit and altered branch orientation. This study measured PAR levels within the same trees receiving sequential treatments: (1), (2), and (7) as described previously.

In 2004, the same PAR sensor clusters were used and installed in a similar manner as in 2003. The arrangement of sensors within the trees was changed. The two tree rows adjacent to the grass row middle were the experimental site. The sensor masts were installed 60 to $80 \mathrm{~cm}$ inside the canopy on the east and west sides of the grass row middle at 1- and 2-m heights. A replicate consisted of two trees on opposite sides of the grass row middle. The portion of the tree facing the grass row middle contained the sensor mast. Each tree had two sensor masts, $1 \mathrm{~m}$ north and $1 \mathrm{~m}$ south of the tree axis. Daily $P A R$ interception was calculated as in 2003 . Incoming $P A R$ was also measured using a $1-\mathrm{m}$ quantum line sensor located in a nonshaded area adjacent to the study area. All fruit were removed from the tree before beginning data collection to prevent branch movement from the weight of fruit/loss of fruit over time. Data were collected as in 2003. Data were collected on both full sun and cloudy days over a 7 - to $10-d$ period in September and early October. Treatments were applied in the following order: 1) untreated control of grass, 2) APF, 3) RPF, 4) $\mathrm{RPF}+\mathrm{PFT}$, 5) APF + PFT, and 6) PFT. After measurement of RPF + PFT, the grass row middle was mowed and the grass clipping removed from the site. This allowed time for the grass to regrow during the APF + PFT treatment and provide a grass cover for the final PFT treatment. All treatments were applied to the two tree rows and the single grass row middle. The PFT and APF treatments were similar to the 2003 application. The repeated measures design had six treatments, three replicates containing two trees, and four positions at each treatment level. This study measured PAR levels within the same trees receiving sequential treatments: (1), (2), (3), (4), and (7), as described previously, and a combination of APF and PFT $(3+7)$.

Reflection of PAR and light at 660 and $730 \mathrm{~nm}$ from the grass treatment of RPF and APF were measured with a field portable spectral radiometer (Unispec; PP Systems, Haverhill, Mass.) within $1 \mathrm{~h}$ of solar noon on 
20 July 2004, a full sun day. The plot was a $1.5-\mathrm{m} \times 2-\mathrm{m}$ area of uniform grass. A cosine-corrected diffuser was attached to the fiber light guide of the radiometer and directed at the grass at $45^{\circ}$ from vertical in both an east and west orientation and a vertical orientation at a $50-\mathrm{cm}$ height over the midpoint of the plot. Incoming radiation was simultaneously measured with a second spectral radiometer located adjacent to the study area. The reflectance from the grass was measured on a single day. The next day, the treatments were applied and the reflectance measured at approximately the same time. Two applications of RPF were made as described in the field study. APF reflectance was measured by placing the APF over the grass surface for both new and APF material that had been in the field study for the entire 2003 growing season.

Reflection of $P A R$ and light at 660 and $730 \mathrm{~nm}$ from the 2004 study were measured with a field portable spectral radiometer (Unispec; PP Systems) within $1 \mathrm{~h}$ of solar noon on 10 Aug. 2004, a full sun day. A cosine-corrected diffuser was attached to the fiber light guide of the radiometer and directed at the ground in a vertical orientation $1 \mathrm{~m}$ over the midpoint of the plot. Incoming radiation was simultaneously measured with a second spectral radiometer located adjacent to the study area in a nonshaded area.

\section{Results}

Canopy PAR levels. In 2002, PAR levels within the canopy were increased by the PFT and RPF treatments (Table 1) as a result of reflection and scatter of $P A R$. PAR levels within the canopy are not only the result of $P A R$ transmission, but also reflection and scatter of $P A R$ into the canopy, which are enhanced by the particle film. Two hours before solar noon ( $2 \mathrm{~h}$ BSN) when the east side is illuminated, $P A R$ levels are higher than the west side. The PFT increased $P A R$ levels in the interior of the canopy only when the canopy was directly illuminated on the east side at $2 \mathrm{~h}$ BSN. The addition of RPF to the PF increased PAR levels in the interior over the control at $2 \mathrm{~h} \mathrm{BSN}$ and $1 \mathrm{~h}$ after solar noon (1 $\mathrm{h} \mathrm{ASN})$ on the east side of the tree. $P A R$ levels below the canopy oriented upward were higher for the PFT + RPF treatment than the control or PFT on the east side $2 \mathrm{~h}$ BSN. The PFT and PFT + RPF were both greater than the control PAR level below the canopy oriented up on the west side for both sampling times. One hour ASN on the east side, the PFT + RPF PAR level below the canopy oriented upward was greater than the control. Light reflected from the orchard floor was measured by the PAR levels below the canopy oriented downward. The east side $P A R$ levels of floor-reflected $P A R$ were greater with the PFT + RPF treatment only. The west side $P A R$ levels of floor-reflected $P A R$ were: $\mathrm{PFT}+\mathrm{RPF}>\mathrm{PFT}>$ control.

In 2003, PAR levels within the canopy were increased by both the APF and the RPF

Table 1. Intercepted $P A R$ levels in 'Empire' apple canopies in 2002.

\begin{tabular}{|c|c|c|c|c|c|}
\hline \multirow[b]{2}{*}{ Treatment $^{z}$} & \multirow[b]{2}{*}{ Side of tree } & \multirow[b]{2}{*}{ Time of day } & \multicolumn{3}{|c|}{ PAR (\% of incoming) } \\
\hline & & & Interior of tree & $\begin{array}{l}\text { Below canopy } \\
\text { oriented upward }\end{array}$ & $\begin{array}{c}\text { Below canopy } \\
\text { oriented downward }\end{array}$ \\
\hline Grass Control & East & $\begin{array}{l}2 \mathrm{~h} \text { before } \\
\text { solar noon }\end{array}$ & $4.6 c^{y}$ & $10.0 \mathrm{~b}$ & $1.1 \mathrm{~b}$ \\
\hline PFT & East & $\begin{array}{l}2 \mathrm{~h} \text { before } \\
\text { solar noon }\end{array}$ & $7.2 \mathrm{~b}$ & $12.8 \mathrm{~b}$ & $1.5 \mathrm{~b}$ \\
\hline $\mathrm{PFT}+\mathrm{RPF}$ & East & $\begin{array}{l}2 \mathrm{~h} \text { before } \\
\text { solar noon }\end{array}$ & $9.6 \mathrm{a}$ & $18.1 \mathrm{a}$ & $2.9 \mathrm{a}$ \\
\hline Grass control & West & $\begin{array}{l}2 \mathrm{~h} \text { before } \\
\text { solar noon }\end{array}$ & $2.8 \mathrm{~b}$ & $6.2 \mathrm{~b}$ & $0.4 \mathrm{c}$ \\
\hline PFT & West & $\begin{array}{l}2 \mathrm{~h} \text { before } \\
\text { solar noon }\end{array}$ & $3.1 \mathrm{ab}$ & $10.4 \mathrm{a}$ & $0.6 \mathrm{~b}$ \\
\hline $\mathrm{PFT}+\mathrm{RPF}$ & West & $\begin{array}{l}2 \mathrm{~h} \text { before } \\
\text { solar noon }\end{array}$ & $3.6 \mathrm{a}$ & $10.4 \mathrm{a}$ & $1.1 \mathrm{a}$ \\
\hline Grass control & East & $\begin{array}{l}1 \mathrm{~h} \text { after } \\
\text { solar noon }\end{array}$ & $1.9 \mathrm{~b}$ & $2.4 \mathrm{~b}$ & $0.2 \mathrm{~b}$ \\
\hline PFT & East & $\begin{array}{l}1 \mathrm{~h} \text { after } \\
\text { solar noon }\end{array}$ & $1.8 \mathrm{~b}$ & $3.0 \mathrm{ab}$ & $0.2 \mathrm{~b}$ \\
\hline $\mathrm{PFT}+\mathrm{RPF}$ & East & $\begin{array}{l}1 \mathrm{~h} \text { after } \\
\text { solar noon }\end{array}$ & $2.1 \mathrm{a}$ & $4.4 \mathrm{a}$ & $0.5 \mathrm{a}$ \\
\hline Grass control & West & $\begin{array}{l}1 \mathrm{~h} \text { after } \\
\text { solar noon }\end{array}$ & 1.9 & $3.6 \mathrm{~b}$ & $0.6 \mathrm{c}$ \\
\hline PFT & West & $\begin{array}{l}1 \mathrm{~h} \text { after } \\
\text { solar noon }\end{array}$ & 2.3 & $5.3 \mathrm{a}$ & $0.7 \mathrm{~b}$ \\
\hline $\mathrm{PFT}+\mathrm{RPF}$ & West & $\begin{array}{l}1 \mathrm{~h} \text { after } \\
\text { solar noon }\end{array}$ & 2.4 & $5.6 \mathrm{a}$ & $1.3 \mathrm{a}$ \\
\hline
\end{tabular}

${ }^{2}$ The treatments were: 1) nontreated control, 2) particle film applied to the entire tree (PFT), and 3) PFT + particle film (RPF) applied to the grass. The particle film treatments were applied to the tree using an orchard blast sprayer delivering $935.4 \mathrm{~L} \cdot \mathrm{ha}^{-1}$. Surround WP concentration was $3 \%$. The reflective particle film (RPF) treatments were applied to grass row middles on each side of the sampled tree row were treated with a $6 \%$ suspension applied at $374 \mathrm{~L} \cdot \mathrm{ha}^{-1}$.

${ }^{y}$ Different letters within a column for each side and time of day indicate a significant difference $(P \leq 0.05)$ using Fisher's protected least significant difference.

treatments (Table 2). The APF and RPF both had greater $P A R$ levels than the control at the 2-m height for both the east and west sides of the tree. The PAR levels at the 1-m height were greatest for the APF, and the RPF was intermediate compared with the control.

In 2004, PAR levels within the canopy were increased on cloudy days by the APF, $\mathrm{PFT}+\mathrm{APF}$, and PFT + RPF treatments on the east and west sides and for both $1-$ and $2-\mathrm{m}$ heights compared with the grass control (Table 3). The RPF and PFT treatments did not significantly increase $P A R$ levels within the canopy on cloudy days compared with the control. On full sun days, $P A R$ levels within the canopy were increased by the PFT + APF and PFT + RPF treatments on the east and west sides and for both 1- and 2-m heights compared with the grass control. The RPF treatment did not significantly increase $P A R$ levels within the canopy compared with the control on full sun days. The APF only increased $P A R$ levels within the canopy on full sun days at the 1- height, whereas the PFR only increased $P A R$ levels within the canopy on full sun days at the 1-m height on the east side compared with the control.

Reflection of radiation from the ground treatments. The RPF material had greater reflection of $P A R$ than the grass (Table 4). The APF material was highly reflective and had reflection greater than all surfaces tested when new and after a growing season. The APF material had the greatest $\mathrm{R} / \mathrm{FR}$ ratio, followed by the RPF material, and grass had the lowest ratio.
Table 2. PAR levels in 'Empire' apple canopies in 2003 with a reflective particle film (RPF) and aluminized plastic film (APF).

\begin{tabular}{|c|c|c|c|c|}
\hline \multirow[b]{3}{*}{ Treatment } & \multicolumn{4}{|c|}{$P A R$ ( $\%$ of incoming) } \\
\hline & \multicolumn{2}{|c|}{ East side } & \multicolumn{2}{|c|}{ West side } \\
\hline & $2 \mathrm{~m} \mathrm{ht}$ & $1 \mathrm{~m} \mathrm{ht}$ & $2 \mathrm{~m} \mathrm{ht}$ & $1 \mathrm{~m} \mathrm{ht}$ \\
\hline Grass control & $5.0 \mathrm{~b}^{\mathrm{z}}$ & $3.3 \mathrm{c}$ & $7.2 \mathrm{~b}$ & $3.0 \mathrm{c}$ \\
\hline Reflective & & & & \\
\hline particle film & $7.9 \mathrm{a}$ & $4.7 \mathrm{~b}$ & $11.5 \mathrm{a}$ & $4.7 \mathrm{~b}$ \\
\hline $\begin{array}{l}\text { Aluminized } \\
\text { plastic film }\end{array}$ & $7.7 \mathrm{a}$ & $5.4 \mathrm{a}$ & $13.4 \mathrm{a}$ & $6.5 \mathrm{a}$ \\
\hline
\end{tabular}

${ }^{2}$ Different letters within a column indicate a significant difference $(P \leq 0.05)$ using Fisher's protected least significant difference.

Fruit weight and color. In 2002, all treatments had fruit weight from the west side of the tree greater than the control (Table 5). There was not a treatment effect on the east side fruit weight or on hue angle from either side. The west side had lower hue angle than the east side across all treatments $(P=0.05)$. A lower hue angle is interpreted as more red color on the apple surface.

In 2003, adjusted average fruit weight from the east side of the tree was increased by the PFW, PFW + RPF, and PFT + RPF treatments and the PFT, APF, and RPF treatments were equivalent to the control (Table 5). Fruit weight from the west side of the tree was increased with the RPF, PFW, and PFW + RPF treatments, whereas the PFT, PFT + $\mathrm{RPF}$, and APF were equivalent to the control. Hue angle from the east side of the tree was reduced in the RPF, PFT+ RPF, and PFW + 
Table 3. Intercepted PAR levels in 'Empire' apple canopies in 2004 receiving reflective treatments to the tree and ground.

\begin{tabular}{lccrrrrrr}
\hline & Sensor & Sky & \multicolumn{7}{c}{ Treatments $^{z}$} \\
\cline { 4 - 8 } Orientation & $\mathrm{ht}(\mathrm{m})$ & conditions & Grass Control & APF & RPF & PFT + RPF & PFT + APF & PFT \\
\hline East & 1 & Cloudy & $3.3 \mathrm{~b}^{\mathrm{y}}$ & $6.7 \mathrm{a}$ & $3.9 \mathrm{~b}$ & $5.9 \mathrm{a}$ & $7.2 \mathrm{a}$ & $3.6 \mathrm{~b}$ \\
East & 2 & Cloudy & $9.3 \mathrm{c}$ & $15.8 \mathrm{a}$ & $9.7 \mathrm{c}$ & $12.3 \mathrm{~b}$ & $15.3 \mathrm{a}$ & $9.5 \mathrm{c}$ \\
West & 1 & Cloudy & $1.7 \mathrm{~b}$ & $3.1 \mathrm{a}$ & $1.7 \mathrm{~b}$ & $3.3 \mathrm{a}$ & $3.5 \mathrm{a}$ & $1.8 \mathrm{~b}$ \\
West & 2 & Cloudy & $4.8 \mathrm{~b}$ & $6.2 \mathrm{a}$ & $5.1 \mathrm{~b}$ & $6.7 \mathrm{a}$ & $6.9 \mathrm{a}$ & $5.2 \mathrm{~b}$ \\
East & 1 & Sunny & $3.3 \mathrm{c}$ & $5.5 \mathrm{a}$ & $4.1 \mathrm{~b}$ & $5.3 \mathrm{a}$ & $5.7 \mathrm{a}$ & $3.7 \mathrm{c}$ \\
East & 2 & Sunny & $4.2 \mathrm{~b}$ & $4.2 \mathrm{~b}$ & $4.0 \mathrm{~b}$ & $4.9 \mathrm{a}$ & $5.0 \mathrm{a}$ & $4.2 \mathrm{~b}$ \\
West & 1 & Sunny & $1.7 \mathrm{~b}$ & $3.2 \mathrm{a}$ & $1.7 \mathrm{~b}$ & $2.7 \mathrm{a}$ & $2.9 \mathrm{a}$ & $1.7 \mathrm{~b}$ \\
West & 2 & Sunny & $4.4 \mathrm{~b}$ & $4.8 \mathrm{~b}$ & $4.6 \mathrm{~b}$ & $5.6 \mathrm{a}$ & $5.3 \mathrm{a}$ & $4.8 \mathrm{~b}$ \\
\hline
\end{tabular}

${ }^{\mathrm{z}}$ The reflective aluminized plastic film (APF) was applied between the tree rows. The particle film (PFT) treatments were applied to the tree using an orchard blast sprayer delivering $935.4 \mathrm{~L} \cdot \mathrm{ha}^{-1}$. Surround WP concentration was $3 \%$. The reflective particle film (RPF) treatments were applied to grass row middles on each side of the sampled tree row were treated with a $6 \%$ suspension of RPF applied at $374 \mathrm{~L} \cdot \mathrm{ha}^{-1}$.

${ }^{y}$ Different letters within a row indicate a significant difference $(P \leq 0.05)$ using Fisher's protected least significant difference.

Table 4. Amount and quality of light reflected from grass, reflective particle films (RPF), and an aluminized reflective plastic (APF) film.

\begin{tabular}{|c|c|c|c|c|}
\hline \multirow[b]{2}{*}{ Treatment } & \multicolumn{2}{|c|}{ Reflected $P A R$ (\% of incoming) } & \multicolumn{2}{|c|}{ Red/far-red ratio $(660 / 730 \mathrm{~nm})$} \\
\hline & $\begin{array}{l}\text { Nonreplicated } \\
\text { study }\end{array}$ & $\begin{array}{c}\text { Replicated } \\
\text { measurements } \\
\text { taken within } \\
\text { the orchard }\end{array}$ & $\begin{array}{l}\text { Nonreplicated } \\
\text { study }\end{array}$ & $\begin{array}{c}\text { Replicated } \\
\text { measurements } \\
\text { taken within } \\
\text { the orchard }\end{array}$ \\
\hline Grass control & 5.1 & $4.2 \mathrm{c}^{\mathrm{x}}$ & 0.12 & $0.33 \mathrm{~d}$ \\
\hline $\begin{array}{l}\text { Reflective particle } \\
\text { film }\end{array}$ & 10.9 & $8.5 \mathrm{~b}$ & 0.38 & $0.51 \mathrm{c}$ \\
\hline $\begin{array}{l}\text { Aluminized plastic } \\
\text { film (new })^{\mathrm{z}}\end{array}$ & 65.5 & & 1.27 & \\
\hline $\begin{array}{l}\text { Aluminized plastic } \\
\text { film (old) } \\
\text { Full sunlight }\end{array}$ & 49.3 & $31.5 \mathrm{a}$ & $\begin{array}{l}1.13 \\
1.33\end{array}$ & $\begin{array}{l}1.10 \mathrm{~b} \\
1.35 \mathrm{a}\end{array}$ \\
\hline
\end{tabular}

${ }^{2}$ The aluminized plastic film was not placed in the orchard.

${ }^{y}$ The aluminized plastic film was placed in the orchard for the 2003 growing season.

${ }^{x}$ Different letters within a column indicate a significant difference $(P \leq 0.05)$ using Fisher's protected least significant difference.

RPF treatments and the PFT, PFW, and APF were equivalent to the control hue angle. Hue angle from the west side of the tree was reduced by all treatments except PFW compared with the control.

In 2004, adjusted average fruit weight from the low, east side of the tree was increased with the PFT + RPF and PFW treatments (Table 6). Fruit weight was increased from the high east side of the tree in the PFT, PFW, and PFW + RPF treatments. No treatment effects on average fruit weight were measured on the inside east or west side of the tree or the west low side of the tree. Fruit weight from the high, west side was increased in the PFW treatment. Hue angle was reduced from both the low and high east side in the RPF, PFW + RPF, and APF treatments. Hue angle from the inside east side was decreased by the RPF treatment. Hue angle from the low, west side was reduced only by the APF treatment. The $\mathrm{PFW}+\mathrm{RPF}$ treatment reduced hue angle from the high and inside west portion of the canopy. Hue angle of apples from the west inside was decreased by the PFT + RPF, $\mathrm{PFW}+\mathrm{RPF}$, and PFW treatments.

There was a significant three-way year $\times$ side of tree $\times$ treatment interaction for fruit weight and hue angle (Tables 5 and 6); however, there was not a significant year $x$ whereas 2003 and 2004 data demonstrated significant effects. The PFT and PFW treatments did improve red color in the west portions of the canopy in 2003 and 2004, respectively. The APF treatment reflected $\approx 6$ to seven times the amount of $P A R$ as the RPF treatments (Table 4) and improved red color in four of the eight sampled areas of the canopy in 2003 (east and west sides) and 2004 (east and west sides at high, low, and inside locations). The RPF, PFT + RPF, and PFW $+\mathrm{RPF}$ improved red color in five, three, and six, respectively, of the eight sampled areas of the canopy in 2003 and 2004 despite reflecting less $P A R$ from the grass treated row middle (Table 4) and generally less canopy $P A R$ interception (Tables 2 and 3) than the APF. The treatments were applied the entire season, not the final 4 to 6 weeks before harvest that is typical of APF use (Miller and Greene, 2003). Apple color development is most affected by canopy light conditions near harvest (Proctor and Creasy, 1971; Proctor and Lougheed, 1976) and high temperature (Saure, 1990).

Layne et al. (2001) measured a 1 to $2{ }^{\circ} \mathrm{C}$ increase in air temperature with APF treatment at midday. This increased temperature did not reduce color development nor advance apple maturity (Layne et al., 2002). Treatment effects on air temperature were not measured in this study. It is possible that the $\approx 30 \%$ increase in PAR reflected by the APF treatment (Tables 2 and 3) could have induced water stress in the trees by raising air temperature that negated the increased $P A R$ and its effect on photosynthesis. However, the seasonal water deficits for 2003 and 2004 were 2 and $21 \mathrm{~cm}$, respectively, and the RPF fruit weight response, compared with APF, was similar in both years (Tables 5 and 6). In addition, analysis of variance (Table 5) did not indicate a year interaction with treatments, which would be expected for a nonwaterstressed year (2003) versus a water-deficit year (2004). So we concluded that the APF was not inducing yield-limiting water stress.

It was expected that the APF treatment would have the most extensive red color development because it had the greatest reflection of PAR compared with the RPF materials (Table 4) and generally the greater increase in canopy light levels (Tables 2 and 3 ). Light quality may be a key factor in this response. Although the RPF materials do not reflect the greatest amount of $P A R$, they do increase the level within the canopy, and the quality of that light is altered by the reflection from grass so that the R/FR ratio is reduced from natural sunlight but increased from grass reflection (Table 4). Proctor and Creasy (1971) found that a fluorescent lamp (1.6 m $\mathrm{W} \cdot \mathrm{cm}^{-2}$ ) had greater promotion of red color in shaded apples than an incandescent lamp $\left(6 \mathrm{~m} \mathrm{~W} \cdot \mathrm{cm}^{-2}\right)$ despite the higher energy level of the incandescent lamp. The florescent lamp had a R/FR ratio $(650 / 750 \mathrm{~nm})>5$, whereas the incandescent had a $\mathrm{R} / \mathrm{FR}$ ratio of 0.72 ; and they concluded that the role of red light to enhance anthocyanin formation is energy level-dependent and depends on prior 
Table 5. Particle film and reflective film effects on 'Empire' apple weight and color in 2002, 2003 and pooled for 2002 to 2004.

\begin{tabular}{|c|c|c|c|c|c|c|c|c|c|}
\hline \multirow[b]{2}{*}{ Treatment $^{\mathrm{z}}$} & \multirow[b]{2}{*}{ Side of tree } & Avg wt (g) & Adjusted wt $(\mathrm{g})^{\mathrm{y}}$ & Hue angle & Avg wt (g) & Adjusted wt $(\mathrm{g})^{\mathrm{y}}$ & Hue angle & Avg wt (g) & Adjusted wt $(\mathrm{g})^{\mathrm{y}}$ \\
\hline & & & 2002 & & \multicolumn{3}{|c|}{2003} & \multicolumn{2}{|c|}{2002 to 2004 pooled data } \\
\hline Grass Control & East & 157 & 153 & 47 & 140 & $140 \mathrm{~b}$ & $71 a^{x}$ & 129 & $131 \mathrm{c}$ \\
\hline RPF & East & 170 & 171 & 48 & 143 & $144 \mathrm{ab}$ & $56 \mathrm{c}$ & 137 & $136 \mathrm{~b}$ \\
\hline PFT & East & 168 & 170 & 51 & 141 & $140 \mathrm{~b}$ & $70 \mathrm{a}$ & 139 & $136 \mathrm{~b}$ \\
\hline $\mathrm{PFT}+\mathrm{RPF}$ & East & 179 & 175 & 41 & 151 & $151 \mathrm{a}$ & $64 \mathrm{~b}$ & 131 & $136 \mathrm{~b}$ \\
\hline PFW & East & 162 & 166 & 45 & 149 & $148 \mathrm{a}$ & $74 \mathrm{a}$ & 145 & $142 \mathrm{a}$ \\
\hline $\mathrm{PFW}+\mathrm{RPF}$ & East & 173 & 175 & 42 & 143 & $144 \mathrm{a}$ & $62 \mathrm{bc}$ & 140 & $138 \mathrm{ab}$ \\
\hline APF & East & ND & ND & $\mathrm{ND}$ & 141 & $141 \mathrm{~b}$ & $67 \mathrm{ab}$ & 134 & $133 \mathrm{bc}$ \\
\hline Grass Control & West & 152 & $125 \mathrm{~b}$ & 45 & 141 & $140 \mathrm{c}$ & $75 \mathrm{a}$ & & \\
\hline RPF & West & 189 & $192 \mathrm{a}$ & 42 & 145 & $147 \mathrm{ab}$ & $65 \mathrm{~b}$ & & \\
\hline PFT & West & 164 & $180 \mathrm{a}$ & 39 & 143 & $142 \mathrm{bc}$ & $64 \mathrm{~b}$ & & \\
\hline $\mathrm{PFT}+\mathrm{RPF}$ & West & 143 & $186 \mathrm{a}$ & 45 & 140 & $138 \mathrm{c}$ & $58 \mathrm{~b}$ & & \\
\hline PFW & West & 172 & $203 \mathrm{a}$ & 42 & 149 & $148 \mathrm{ab}$ & $72 \mathrm{ab}$ & & \\
\hline $\mathrm{PFW}+\mathrm{RPF}$ & West & 174 & $190 \mathrm{a}$ & 42 & 149 & $152 \mathrm{a}$ & $56 \mathrm{~b}$ & & \\
\hline APF & West & $\mathrm{ND}^{\mathrm{w}}$ & $\mathrm{ND}$ & ND & 137 & $138 \mathrm{c}$ & $60 \mathrm{~b}$ & & \\
\hline
\end{tabular}

${ }^{2}$ The treatments were: 1) nontreated control, 2) reflective particle film (RPF) applied to the grass, 3) particle film applied to the entire tree (PFT), 4) PFT + RPF, 5) particle film applied only to the west side (PFW) of the tree, 6) PFW+ RPF, and 7) aluminized plastic film (APF) applied to the grass.

${ }^{y}$ Values are adjusted means based on the mean number of fruit per tree. Different letters within a column for a side, indicate a significant difference $(P \leq 0.05)$ based on analysis of covariance using the number of fruit per tree as the covariate.

${ }^{\times}$Different letters within a column for a side indicate a significant difference $(P \leq 0.05)$ using Fisher's protected least significant difference.

"No data.

Table 6. Particle film and reflective film effects on 'Empire' apple weight and color in 2004.

\begin{tabular}{|c|c|c|c|c|c|c|c|c|c|c|}
\hline Treatment $^{\mathrm{z}}$ & Side & Position & Avg wt (g) & Adjusted $\mathrm{wt}^{\mathrm{y}}(\mathrm{g})$ & Hue angle & Side & Position & Avg wt (g) & Adjusted wt (g) & Hue angle \\
\hline Grass control & East & Low & 162 & $161 \mathrm{~b}$ & $65 \mathrm{a}^{\mathrm{x}}$ & West & Low & 163 & 162 & $67 \mathrm{a}$ \\
\hline RPF & East & Low & 170 & $166 \mathrm{ab}$ & $50 \mathrm{~b}$ & West & Low & 158 & 157 & $63 \mathrm{a}$ \\
\hline PFT & East & Low & 167 & $161 \mathrm{~b}$ & $67 \mathrm{a}$ & West & Low & 172 & 170 & $69 \mathrm{a}$ \\
\hline PFT + RPF & East & Low & 167 & $180 \mathrm{a}$ & $65 \mathrm{ab}$ & West & Low & 151 & 157 & $59 \mathrm{ab}$ \\
\hline PFW & East & Low & 183 & $181 \mathrm{a}$ & $66 \mathrm{a}$ & West & Low & 177 & 176 & $68 \mathrm{a}$ \\
\hline $\mathrm{PFW}+\mathrm{RPF}$ & East & Low & 167 & $164 \mathrm{~b}$ & $48 \mathrm{~b}$ & West & Low & 175 & 174 & $65 \mathrm{a}$ \\
\hline APF & East & Low & 160 & $162 \mathrm{~b}$ & $53 \mathrm{~b}$ & West & Low & 169 & 170 & $50 \mathrm{~b}$ \\
\hline Grass control & East & High & 153 & $154 \mathrm{~b}$ & $51 \mathrm{a}$ & West & High & 174 & $174 \mathrm{~b}$ & $46 \mathrm{a}$ \\
\hline RPF & East & High & 168 & $170 \mathrm{ab}$ & $42 \mathrm{~b}$ & West & High & 169 & $169 \mathrm{~b}$ & $42 \mathrm{ab}$ \\
\hline PFT & East & High & 182 & $186 \mathrm{a}$ & $50 \mathrm{a}$ & West & High & 172 & $172 \mathrm{~b}$ & $48 \mathrm{a}$ \\
\hline $\mathrm{PFT}+\mathrm{RPF}$ & East & High & 176 & $168 \mathrm{ab}$ & $45 \mathrm{ab}$ & West & High & 173 & $172 \mathrm{~b}$ & $42 \mathrm{ab}$ \\
\hline PFW & East & High & 183 & $186 \mathrm{a}$ & $43 \mathrm{ab}$ & West & High & 207 & $207 \mathrm{a}$ & $45 \mathrm{a}$ \\
\hline $\mathrm{PFW}+\mathrm{RPF}$ & East & High & 177 & $179 \mathrm{a}$ & $38 \mathrm{~b}$ & West & High & 175 & $175 \mathrm{~b}$ & $38 \mathrm{~b}$ \\
\hline APF & East & High & 176 & $175 \mathrm{ab}$ & $42 \mathrm{~b}$ & West & High & 168 & $168 \mathrm{~b}$ & $43 \mathrm{ab}$ \\
\hline Grass control & East & Inside & 170 & $169 \mathrm{ab}$ & $82 \mathrm{a}$ & West & Inside & 170 & 170 & $85 \mathrm{a}$ \\
\hline RPF & East & Inside & 157 & $156 \mathrm{~b}$ & $65 \mathrm{~b}$ & West & Inside & 171 & 169 & $80 \mathrm{a}$ \\
\hline PFT & East & Inside & 171 & $170 \mathrm{ab}$ & $77 \mathrm{a}$ & West & Inside & 183 & 182 & $77 \mathrm{a}$ \\
\hline $\mathrm{PFT}+\mathrm{RPF}$ & East & Inside & 164 & $168 \mathrm{ab}$ & $74 \mathrm{ab}$ & West & Inside & 172 & 177 & $63 \mathrm{~b}$ \\
\hline PFW & East & Inside & 186 & $185 \mathrm{a}$ & $69 \mathrm{ab}$ & West & Inside & 184 & 183 & $66 \mathrm{~b}$ \\
\hline $\mathrm{PFW}+\mathrm{RPF}$ & East & Inside & 188 & $187 \mathrm{a}$ & $69 \mathrm{ab}$ & West & Inside & 184 & 183 & $64 \mathrm{~b}$ \\
\hline APF & East & Inside & 168 & $168 \mathrm{ab}$ & $70 \mathrm{ab}$ & West & Inside & 175 & 176 & $71 \mathrm{ab}$ \\
\hline
\end{tabular}

${ }^{2}$ The treatments were: 1) nontreated control, 2) reflective particle film (RPF) applied to the grass, 3) particle film applied to the entire tree (PFT), 4) PFT + RPF, 5) particle film applied only to the west side (PFW) of the tree, 6) PFW+ RPF, and 7) aluminized plastic film (APF) applied to the grass.

${ }^{y}$ Values are adjusted means based on the mean number of fruit per tree. Different letters within a column indicate a significant difference $(P \leq 0.05)$ based on analysis of covariance using the number of fruit per tree as the covariate.

${ }^{x}$ Different letters within a column for each side and position indicate a significant difference $(P \leq 0.05)$ using Fisher's protected least significant difference.

exposure of the apple skin to a high-energy source. This relationship argues against the $\mathrm{R} / \mathrm{FR}$ ratio of the RPF treatment as a factor to increase red apple color. However, Finlayson et al. (1999) and Knee et al. (2000) have demonstrated that increased far-red radiation in the light environment can enhance ethylene action in maturation, which could enhance red color development during apple maturation, particularly without an increase in peel temperature (Saure, 1990). Increased far-red radiation has also increased volatiles in strawberry (Loughrin and Kasperbauer, 2002), nutrient content of carrots (Antonious and Kasperbauer, 2002), and terpene accumulation in cotton (Kasperbauer and Loughrin, 2004). It is not clear what mechanisms are responsible for the increased red color from the RPF treatments, but increased red color is not directly related to canopy $P A R$ levels.
In all years, average fruit weight was increased by the treatments compared with the untreated control (Table 5) except for the APF treatment. In 2002, the enhanced effect of the RPF on fruit weight was unexpected and the APF treatment was added in 2003 and 2004 to clarify the response. The consistent increase in fruit weight by the RPF treatment and the neutral effect of APF indicated that other factors were influencing dry matter partitioning to the fruit. Grout et al. (2004) reported that the season-long use of a woven white APF with an R/FR ratio of 1.06 increased yield and size of apple. Work with far-red radiation reflecting red plastic mulch has demonstrated that the change in light quality results in an increase of dry matter partitioning to developing fruit (Fortnum and Kasperbauer, 1992; Kasperbauer, 1987, 2000; Kasperbauer and Hunt, 1998; Kasperbauer and Karlen, 1986; Matheny et al., 1992). The phytochrome system is a primary receptor of light environmental cues that indicate competition from other plants and the changing season, and it is a key mechanism in altering dry matter partitioning to ensure plant survival and reproduction (Kasperbauer, 2000). The R/FR ratio of the APF (1.27) was similar to nonreflected full sun (1.33 and 1.35 from Table 4). Mulch R/FR ratios of 0.78 to 0.83 (Hunt et al., 1990; Matheny et al., 1992) and plant competition with R/FR ratios of 0.29 to 0.58 (Kasperbauer, 1987; Kasperbauer and Karlen, 1986) are similar to the ratios of the RPF of 0.38 to 0.51 (Table 4) and are sufficiently low to have a measurable biologic effect. Kasperbauer (1992) reported several studies in which the greatest amount of intercepted PAR did not result in the greatest accumulation of biomass, further 
emphasizing the importance of light quality on dry matter accumulation and partitioning. The present study supports this concept because the APF reflected more PAR into the apple canopy than the RPF treatments, yet fruit weight was unaffected. The PFW and PFW + RPF had the highest fruit weights of the 3-year study, likely as a result of reduced heat stress (Glenn et al., 2001, 2003) on the west side of the tree in combination with light reflection from the west side toward the east side in the afternoon. The PFW and PFW + RPF treatments were not evaluated in the separate canopy light study, but would be expected to have canopy light interception slightly lower than the PFT and PFT + RPF treatments. The PF treatment has consistently increased 'Empire' fruit weight (Glenn et al., 2001,2003 ) as a result of reduced canopy temperature and reduced heat stress leading to increased whole canopy photosynthesis. Increased $P A R$ within the canopy was measured (Tables 1, 2, and 3 ) but was not a large addition of light to the energy budget. An additional mechanism responsible for the increase fruit weight may be the altered light quality, not quantity, reflected from one PFtreated tree to another because the reflected light from the tree would be similar to treated grass. In earlier studies (Glenn et al., 2001) $\mathrm{PF}$ application in the first half of the growing season resulted in improved red color development and fruit weight at harvest, yet red color development is generally improved by light conditions near harvest suggesting that a phytochrome-mediated signal may be generated in the early portion of the growing season that has season-long effects.

In conclusion, it appears that light reflected from the grassed row middle and perhaps adjacent trees has beneficial effects on both fruit color and fruit weight. Reflecting $P A R$ with an APF clearly improved red color development with no effect on fruit weight. Reflecting a lesser amount of $P A R$ with enhanced far-red radiation may enhance red color development and consistently increased fruit weight. The effect of enhanced far-red radiation on increased fruit weight may be a phytochrome-mediated process affecting dry matter partitioning; the effect on pigment development requires further investigation.

\section{Literature Cited}

Antonious, G.F. and M.J. Kasperbauer. 2002. Color of light reflected to leaves modifies nutrient content of carrot roots. Crop Sci. 42:1211-1216.

Finlayson, S.A., I.J. Lee, J.E. Mullet, and P.W. Morgan. 1999. The mechanism of rhythmic ethylene production in sorghum. The role of phytochrome B and simulated shading. Plant Physiol. 119:1083-1089.

Fortnum, B.A. and M.J. Kasperbauer. 1992 Biomass partitioning and root-knot nematode development in tomato plants under end-of-day red or far-red light. Crop Sci. 32:408-411.

Glenn, D.M., S. Drake, J.A. Abbott, G.J. Puterka, and P. Gundrum. 2005. Season and cultivar influence the fruit quality response of apple cultivars to particle film treatments. HortTechnology 15:249-253.

Glenn, D.M., A. Erez, G.J. Puterka, and P. Gundrum. 2003. Particle films affect carbon assimilation and yield in 'Empire' apple. J. Amer. Soc. Hort. Sci. 128:356-362.

Glenn, D.M., G.J. Puterka, S. Drake, T.R. Unruh, A.L. Knight, P. Baherle, E. Prado, and T. Baugher. 2001. Particle film application influences apple leaf physiology, fruit yield and fruit quality. J. Amer. Soc. Hort. Sci. 126: $175-181$.

Green, S.R., K.G. McNaughton, D.H. Greer, and D.J. McLeod. 1995. Measurements of increased PAR and net all-wave radiation absorption by an apple tree caused by applying a reflective ground covering. Agr. For. Meteorol. 76:163-183.

Grout, B.W.W., C.V. Beale, and T.P.C. Johnson. 2004. The positive influence of year-round reflective mulch on apple yield and quality in commercial orchards. Acta Hort. 636:513 519 .

Hampson, C.R., G.A. Quamme, F. Kappel, and R.T. Brownlee. 2004. Varying density with constant rectangularity: I. Effects on apple tree growth and light interception in three training systems over ten years. HortScience 39:501506.

Hunt, P.G., T.A. Matheny, and M.J. Kasperbauer. 1990. Cowpea yield response to light reflected from different colored mulches. Crop Sci. 30:1292-1294.

Kasperbauer, M.J. 1987. Far-red light reflection from green leaves and effects on phytochromemediated assimilate partitioning under field conditions. Plant Physiol. 85:350-354.

Kasperbauer, M.J. 1988. Phytochrome involvement in regulation of the photosynthetic apparatus and plant adaptation. Plant Physiol. Biochem. 26:519-524.

Kasperbauer, M.J. 1992. Phytochrome regulation of morphogenesis in green plants: From the Beltsville spectrograph to colored mulch in the field. Photochem. Photobiol. 56:823-832.

Kasperbauer, M.J. 1999. Developing technology: Colored mulch for food crops. Chemtech 29:45-50.

Kasperbauer, M.J. 2000. Strawberry yield over red versus black plastic mulch. Crop Sci. 40:171174

Kasperbauer, M.J. and P.G. Hunt. 1992. Cotton seedling morphogenic responses to FR/R ratio reflected from different colored soils and soil covers. Photochem. Photobiol. 56:579-584.

Kasperbauer, M.J. and P.G. Hunt. 1998. Far-red light affects photosynthate allocation and yield of tomato over red mulch. Crop Sci. 38:970974.

Kasperbauer, M.J. and D.L. Karlen. 1986. Lightmediated bioregulation of tillering and photosynthate partitioning in wheat. Physiol. Plant. 66:159-163.

Kasperbauer, M.J. and J.H. Loughrin. 2004. Morphogenic light reflected to developing cotton leaves affects insect-attracting terpene concentrations. Crop Sci. 44:198-203.

Kaul, K. and M.J. Kasperbauer. 1992. Mulch color effects on reflected light, rhizosphere temperature and pepper yield. Trans. Ky. Acad. Sci. 53:109-112.

Knee, E.M., R.P. Hangarter, and M. Knee. 2000. Interactions of light and ethylene in hypocotyls hook maintenance in Arabidopsis thaliana seedling. Physiol. Plant. 108:208-215.

Layne, D.R., Z. Jiang, and J.W. Rushing. 2001. Tree fruit reflective film improves red skin coloration and advances maturity in peach. Hort Technology 11:234-242.

Layne, D.R., Z. Jiang, and J.W. Rushing. 2002. The influence of reflective film and ReTain on red skin coloration and maturity of 'Gala' apples. HortTechnology 12:640-645.

Loughrin, J.H. and M.J. Kasperbauer. 2002. Aroma of fresh strawberries is enhanced by ripening over red versus black mulch. J. Agr. Food Chem. 50:161-165.

Matheny, T.A., P.G. Hunt, and M.J. Kasperbauer. 1992. Potato tuber production in response to reflected light from different colored mulches. Crop Sci. 32:1021-1024.

Miller, S.S. 1988. Plant bioregulators in apple and pear culture. Hort. Rev. (Amer. Soc. Hort. Sci). 10:309-401.

Miller, S.S. and G.M. Greene. II. 2003. The use of reflective film and ethephon to improve red skin color of apples in the mid-Atlantic region of the United States. HortTechnology 13:9099 .

Moreshet, S., G. Stanhill, and M. Fuchs. 1975. Aluminum mulch increases quality and yield of 'Orleans' apples. HortScience 10:390 391.

Proctor, J.T.A. and L.L. Creasy. 1971. Effect of supplementary light on anthocyanin synthesis in 'McIntosh' apples. J. Amer. Soc. Hort. Sci. 96:523-526.

Proctor, J.T.A. and E.C. Lougheed. 1976. The effect of covering apples during development. HortScience 11:108-109.

Rajapakse, N.C. and J.W. Kelly. 1992. Regulation of Chrysanthemum growth by spectral filters. J. Amer. Soc. Hort. Sci. 117:481-485.

Saure, M.C. 1990. External control of anthocyanin formation in apple. Sci. Hort. 42:181-218.

Shahak, Y., E.E. Gussakovsky, Y. Cohen, S. Lurie, R. Stern, S. Kfir, A. Naor, I. Atzmon, I. Doron, and Y. Greenblat-Avron. 2004. ColorNets: A new approach for light manipulation in fruit trees. Acta Hort. 636:609-616.

Williams, M.W. and H.D. Billingsley. 1974. Effect of nitrogen fertilizer on yield, size, and color of 'Golden Delicious' apple. J. Amer. Soc. Hort. Sci. 99:144-145. 